\title{
Expanding inter-professional interactions and territories, an analysis of an experience in methodological change in a multiprofessional primary care residency program
}

\author{
Expandir interações e territórios interprofissionais, análise a partir de mudança metodológica em programa de \\ residência multiprofissional em atenção primária
}

\section{Alexandre PADILHA ${ }^{1}$}

Thais AMORIM ${ }^{2}$

Jessica LEMOS²

Patrícia $\mathrm{TOZZO}^{3}$

\section{ABSTRACT}

Multiprofessional teams and health training centered around these teams reduce the fragmentation of health systems. The Brazilian experience in services and training shows how interprofessional education remains a challenge. With the purpose of reflecting on this theme, we analyze a change in methodological strategy in a multiprofessional residency program at a philanthropic university in a Brazilian metropolis. We describe the workshops and their results in a synthesis matrix, categorizing knowledge and professional practices into 4 dimensions: management of health care, of health services, of health services network and of health policy. Our analysis of the results was based on theoretical references of the interdisciplinary professional health training and knowledge production. The results reveal an increase in interprofessional interaction, the development of interdisciplinary knowledge and the expansion of the professional territory. It contributed to the multiprofessional residence program where the initiative was carried out and to reflections on interprofessional education.

Keywords: Comprehensive Health Care. Primary Health Care. Interprofessional Education. Medical Education.

\section{RESUMO}

Equipes multiprofissionais e a formação em saúde ancorada nestas equipes, diminuem a fragmentação dos sistemas de saúde. A experiência brasileira nos serviços e na formação, mostram como a educação interprofissional é um desafio. Com o objetivo de refletirmos sobre este tema, analisamos a experiência da mudança de estratégia metodológica em um programa de residência multiprofissional em uma universidade filantrópica em uma metrópole brasileira. Descrevemos as oficinas e seus resultados em suas matrizes síntese, compreendendo saberes e práticas profissionais em 4 dimensões: gestão do cuidado, do serviço, da rede de atenção e da política de saúde. Analisamos os resultados a partir de referências teóricas da produção interdisciplinar do conhecimento e da formação profissional em saúde. Os resultados revelam uma ampliação na interação interprofissional, na construção de saberes interdisciplinares e na expansão do território profissional, contribuindo para o programa de residência multiprofissional no qual a intervenção foi realizada e para as reflexões sobre a educação interprofissional.

Palavras-Chaves: Atenção Integral a Saúde. Atenção Primária a Saúde. Educação Interprofissional. Educação Médica.

\section{INTRODUCTION}

The development of Brazil's public health system (Sistema Único de Saúde - SUS) means not only the universalization of what is already offered in health but, as stated by Campos [1], a change in the technical assistance model, which is strongly defined by a biomedical perspective, economic and political interests, and by acricital technology incorporation. According to Andrade [2], a paradigmatic tension between models has been produced over the course of the past 30 years. We consider that the training process for health professionals should contribute to this tension, in the sense of encouraging a broad clinical practice, the use

\footnotetext{
${ }^{1}$ Health Department - Nove de Julho University and Public Health Departament. Medical Science School- University of Campinas. Rua Vergueiro 235/249, Liberdade, São Paulo, SP, Brasil. Correspondência para / Correspondence to: A PADILHA. E-mail: <padilha.alexandre@gmail.com>

2 Primary Care Multiprofessional Residence Program, Nove de Julho University. São Paulo, SP, Brasil.

${ }^{3}$ Health Department, Nove de Julho University. São Paulo, SP, Brasil.

$\otimes \otimes \square \otimes \square$

Como citar este artigo / How to cite this article

Padilha A, Amorim T, Lemos J, Tozzo P. Expanding inter-professional interactions and territories, an analysis of an experience in methodological change in a multiprofessional primary care residency program. InterAm J Med Health 2019;2:e201901002. http://dx.doi.org/10.31005/iajmh.v2002
} 
of light technologies in care [3], a view of the patient as persons, and overcoming the epidemiological notion of risks towards appropriating the concept of vulnerability. All of this issues promotes integral practices, as explained by Aires [4].

The establishment of multiprofessional teams in health is becoming an important tool in the reorganization of the healh team working process. It broaden perspectives and knowledge in health care in addition to offering gains in efficacy. As stated by Ceccim et al. [5], the goal is a more integral and resolutive care, resulting from expressing and interacting with a variety of professional practices, different epistemic perspectives and clinical actions, in response to the challenge of responding to the patient concrete health needs. In a way, what is reinforced is the understanding that seeking for integrality includes, as one of its pillars, the establishment of multiprofessional teams in the care facilities of an integrated care network. The teams contribute to the organization of knowledge, therapeutic projects, perspectives and attitudes, comprising what Kalichman [6] has described as one of the axis on which the practice of integrality is built: the axis of articulations.

Within the context of health policy and the organization health assistance, multiprofessional practice has developed in a variety of arrangements, based on the composition of the teams, the interaction between areas of knowledge, and the organization of its working processes. To this aim, matrix management of multiprofessional collaboration on primary care was incorporated into the Brazilian Health System National Humanization Policy (Política Nacional de Humanização do SUS) [7] and the National Primary Healthcare Policy (Política Nacional de Atenção Básica do SUS ) [8]. Two main concepts were incorporated on them. The concept of collaborative supervision and support: institutional collaborative support, the specialist who shares their knowledge and decisions with other professionals towards the goal of developing a therapeutic plan or health intervention; and the concept of the matrix collaboration: establishing relationships that are not strictly vertical, between levels of command, or horizontal, between same professional partners. The matrix collaboration stabilishes new relationships among areas of knowledge, core skills, and organizational arrangements. The concepts of matrix collaborative support have gained legitimacy and have expanded in the organization of services. As a result, they have influenced the guidelines for professional health training, especially guidelines for multiprofessional training and primary healthcare.

A number of challenges have been stated since the beginning of the multiprofessional residency programs. These are [9]: the pedagogical process; how to combine the aspect of training and also transformative action during primary care attention experiencing, how to join broaden visions of health with a mode of organization and reproduction of knowledge still based on a biomedical model; how to insert this into a strategy for the development of integrated health systems; the need to systematize innovative practices within a diverse context of experiences; and how to think about the evaluation of residents and the residency program's pedagogical process itself, facing the students as active agents during the whole process.

Dealing with thesechallengesina Multiprofessional Residency program funded by the Department of Health at Universidade Nove de Julho (UNINOVE), in the city of São Paulo, we analyzed a methodological initiative whose goal was to promote greater interaction between areas of knowledge and each professional specific practices. The report of this experience seeks to reflect on how we can expand the collective production of knowledge and practices between professionals while expanding the residents' interactions with the health system and its health policies.

\section{METHODS}

This article analyzes a pedagogical initiative, describing the methodologies and results of what were called "matrix workshops," conducted at a Multiprofessional Residency Program for Primary Care and Family Health, at Universidade Nove de Julho (UNINOVE), located in the city of São Paulo. At all, 24 multiprofessional residents took part, among them were 12 first year and 12 second year residents, from six different professions: Nursing, Pharmacy, Physiotherapy, Nutrition, Dentistry and Psychology.

The first stage consisted of 6 weekly meetings, lasting 4 hours each. The meetings began with a 1-hour oral presentation by the residents of each profession, on the knowledge that was systematized during the first year of the program under the guidelines, technologies and practices of each profession in Primary Healthcare, covering theory and practical exercises. The presentation was followed by questions and discussions mediated by 
the professor about the knowledge and practices of each profession within the context of Primary Care. A record of the workshops was systematized into a report by profession by its respective residents. At the end of the workshops, based on the contributions from the residents, a matrix of the knowledge and practices offered by each profession was created, with 4 dimensions: Management of care, comprising of the possibilities for meetings between the professional and the patient; Management of service, on the possibilities to organize a Basic Health Unit (Unidade Básica de Saúde) and the workimg processes of the Family Health Strategy (Estratégia Saúde da Família) team; Management of the network, on the needs and possibilities for dialogue and integration with other healthcare services, based on primary care; and, finally, management of SUS and the possibilities to define regulatory frameworks and policy and budget rules.

The second stage took place over 5 weekly workshops, lasting 4 hours each, mediated by the same professor, with the residents initially divided into groups by profession. Each group filled out a matrix that presented knowledge and practices presented by profession, along the 4 dimensions; Management of Care, Management of Health Services, Management of the Health Network, and Management of SUS and Health Policies. Each workshop had a theme and specific population, namely: Homeless population; LGBT population - lesbians, gays, bissexuals, transvetites, transsexuals and transgender; Immigrant population; and Population with problematic use of alcohol and other drugs. After each presentation by professional area, a discussion mediated by the professor took place. The third stage took place over 4 weekly workshops, lasting 4 hours each, following the same methodology as the second phase, with each covering the respective themes: children and adolescent health; women's health/pregnancy; men's health; and elderly health.

During each workshop in the second and third phase, the residents used the respective national guidelines and current Basic Care booklets from the National Department of Health, municipal or state recommendations by theme, and academic articles recommended by the professor that connected these themes to Primary Healthcare as reference reading material. The results of the workshops were systematized into a matrix by theme, based on the contributions made by the residents. The content of the workshops was permanently applied during other activities during the Multiprofessional Residency Progthem both medianted by the same professor: thematic discussions with participants from the municipal health system (Rodas de Conversa) and clínicas discussions of individual therapeutic plans for difficult patient cases treated at the Residency Program's Basic Health Units.

\section{RESULTS}

Workshops were conducted for each profession, presented by 4 professionals from each field, coming to a total of 24 multiprofessional residents, presented in the following order: Pharmacy, Physiotherapy, Nursing, Psychology, Nutritionists and Dental Surgeons. The table below offers an overview of the knowledge and practices presented by each profession, along 4 dimensions: Management of Care, of Service, of the Network, and of Public Health.

Table 1. Matrix of workshops by profession.

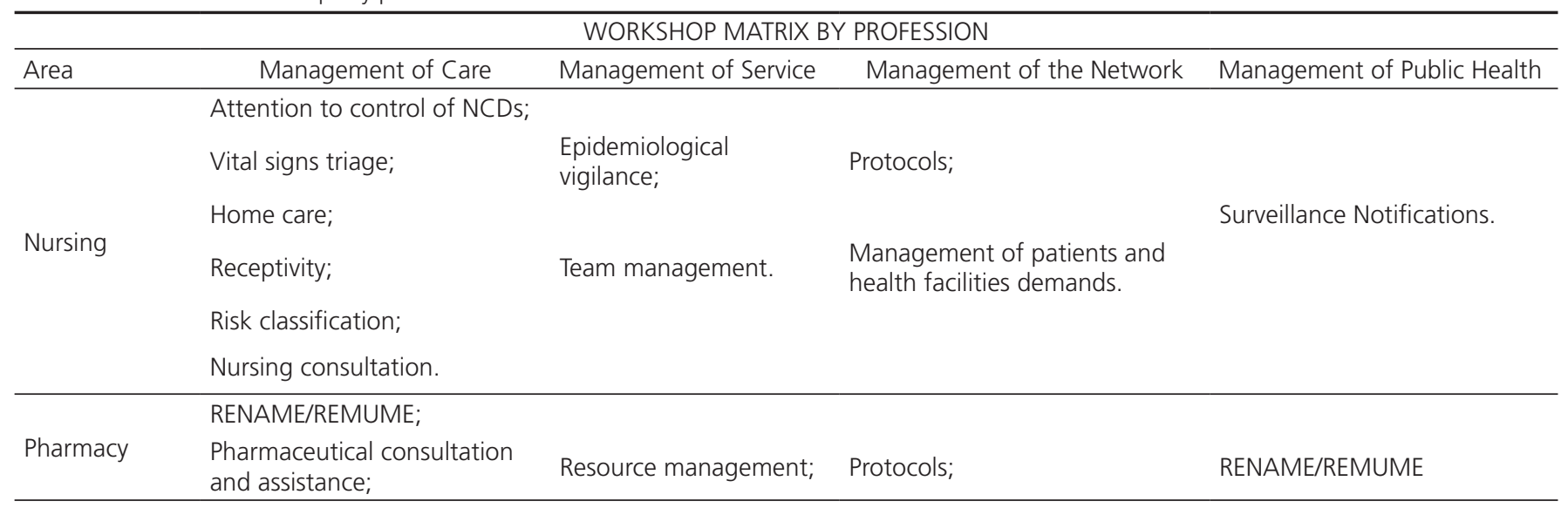




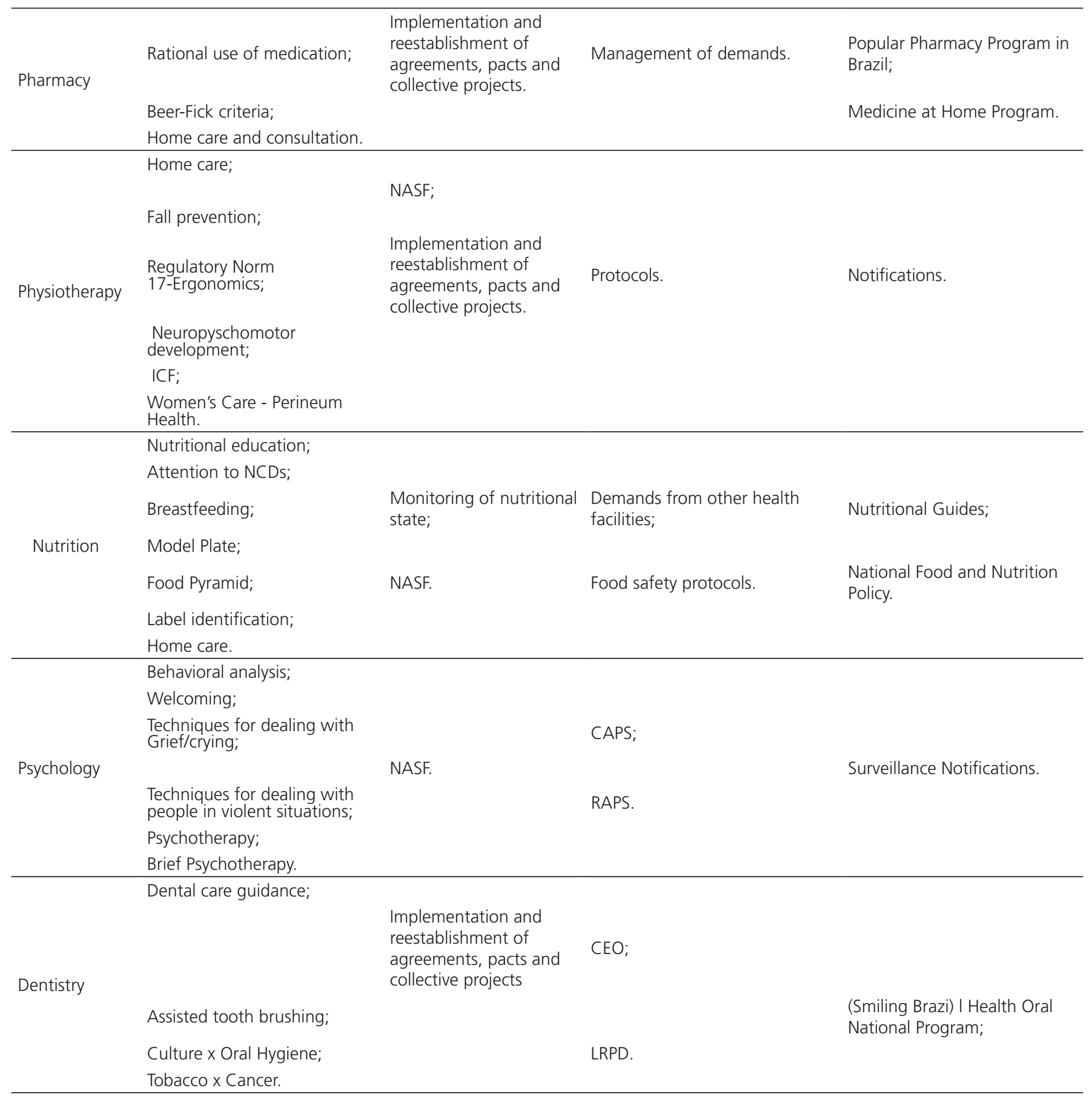

The results presented in Table 1 show how developing the matrix through each profession relationship with the management of care dimension led to each profession evidence its specific knowledge, practices and tasks. Some examples in relation to knowledge: Risk classification (nursing); Beer-Fick Criteria, RENAME/ REMUME (pharmacy); Regulatory Norm 17-Ergonomics and International Classification of Functioning, Disability and Health (ICF) (physiotherapy); Model Plate and Food Pyramid (nutrition); Techniques for dealing with grief/ crying and Techniques for dealing with people in violent situations (psychology); Tobacco x Oral cancer (Dentistry). Some examples in relation to practices: Assisted tooth brushing (dentistry); Brief psychotherapy (psychology); Label identification (nutrition); Perineum health (physiotherapy); Signal triage (nursing). Some examples 
of tasks: Active search for cancer (dentistry); Welcoming seen as a task in nursing and psychology, rather than an attitude throughout service; Breastfeeding (nutrition); Prevention of falls and neuropsychomotor development (physiotherapy). Home care appears only for nursing, pharmacy and physiotherapy. Four professions pointed out a need for specific consultations: pharmacy, nutrition, dentistry and nursing.

Still on Table 1, the contributions presented for the dimension of service management are related to specific tasks: Epidemiological Vigilance and Team management (nursing); Coordination of resources (pharmacy); making up part of the Family Health Support Team (NASF) (psychology, physiotherapy and nutrition). In the system management dimension, the contributions are in the sense of demands for specific services by profession (CEO, CAPS/RAPS, Long stay services), standardizing specific protocols by profession, and specific tasks (managing demands and workflows, such as in nursing and pharmacy). Only the Pharmacy, Nutrition and Dentistry categories presented contributions for the Public Health Management dimension, related to specific programs/policies (Popular Pharmacy, Medicine at home, National Food and Nutrition Policy, and Smiling Brazil Program) or normative tasks by profession, such as surveillance notifications (nursing, nutrition and psychology).

Table 2 below shows an example of a matrix built during the second stage of this initiative. In this example, the theme for the matrix is homeless population. Five workshops were held on themes about vulnerable populations, with 24 participants in each.

Table 2. Matrix homeless population.

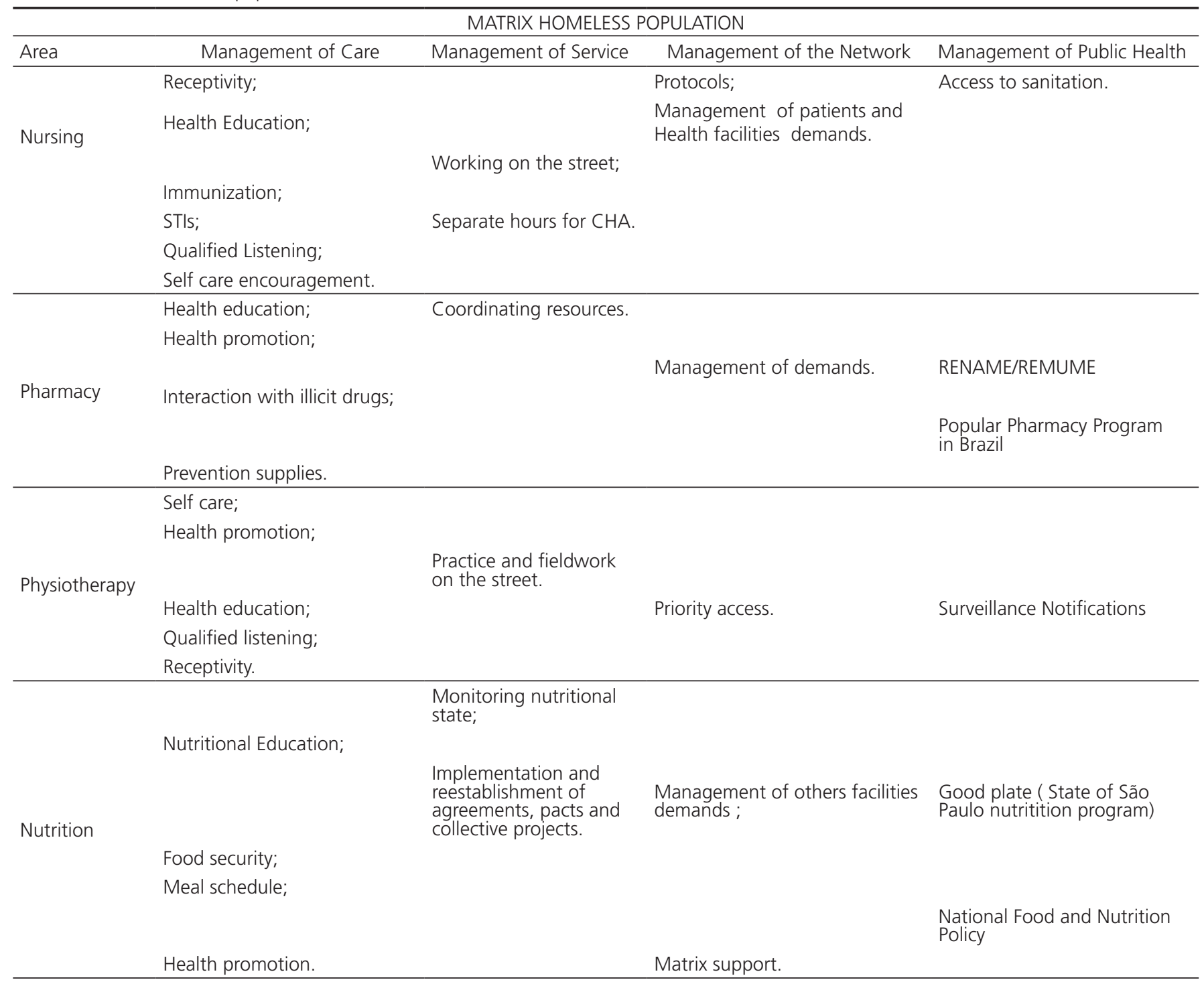




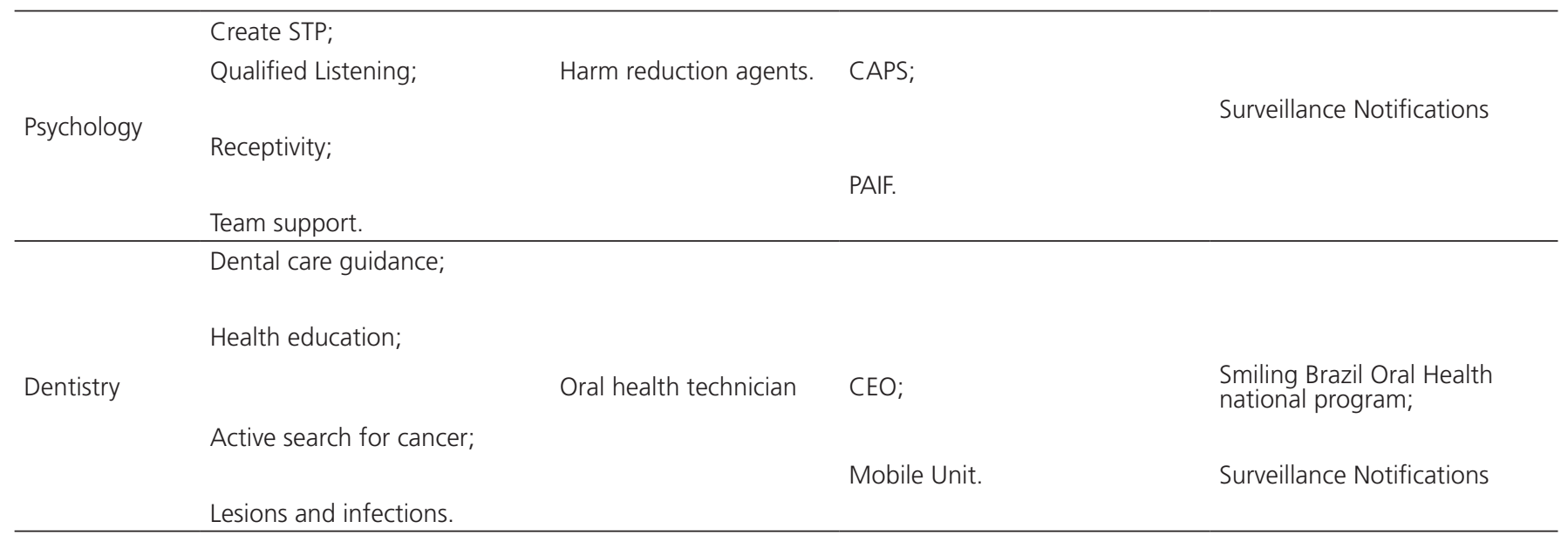

The results of the example presented in Table 2 show how the contributions presented for vulnerable populations were common to more than one profession: qualified listening/welcoming reception (nursing, psychology and physiotherapy); health education/health promotion/self care (nursing, dentistry, pharmacy, nutrition and physiotherapy). The professional areas of Psychology, Pharmacy, Nursing and Nutrition presented specific knowledge and practices: Active search for cancer, oral lesions and infections, immunization, interaction with illicit drugs, food safety, team psychological support. In the service management dimension, common contributions were made, indicating a rearrangement of work processes or team organization: Oral health technician, harm reduction agent, practical activities on the street, health team visits inlesionaste unit territory, and adaptation of work schedule for Community Health Agents (CHA). In network management, contributions were made for more professions, related to specific health facilities: Mobile dental unit, CEO, CAPS, Family Support Program (social assistance), and matrix support. In public health management, intersector policies (food security), specific programs, and regulatory tasks appear as contributions from almost all professions in the example presented.

Four workshops were conducted with a focus on life stages, with 24 participants in each. A matrix was produced in each workshop, like the one presented in Table 3 in reference to elderly population.

Table 3. Elderly population matrix.

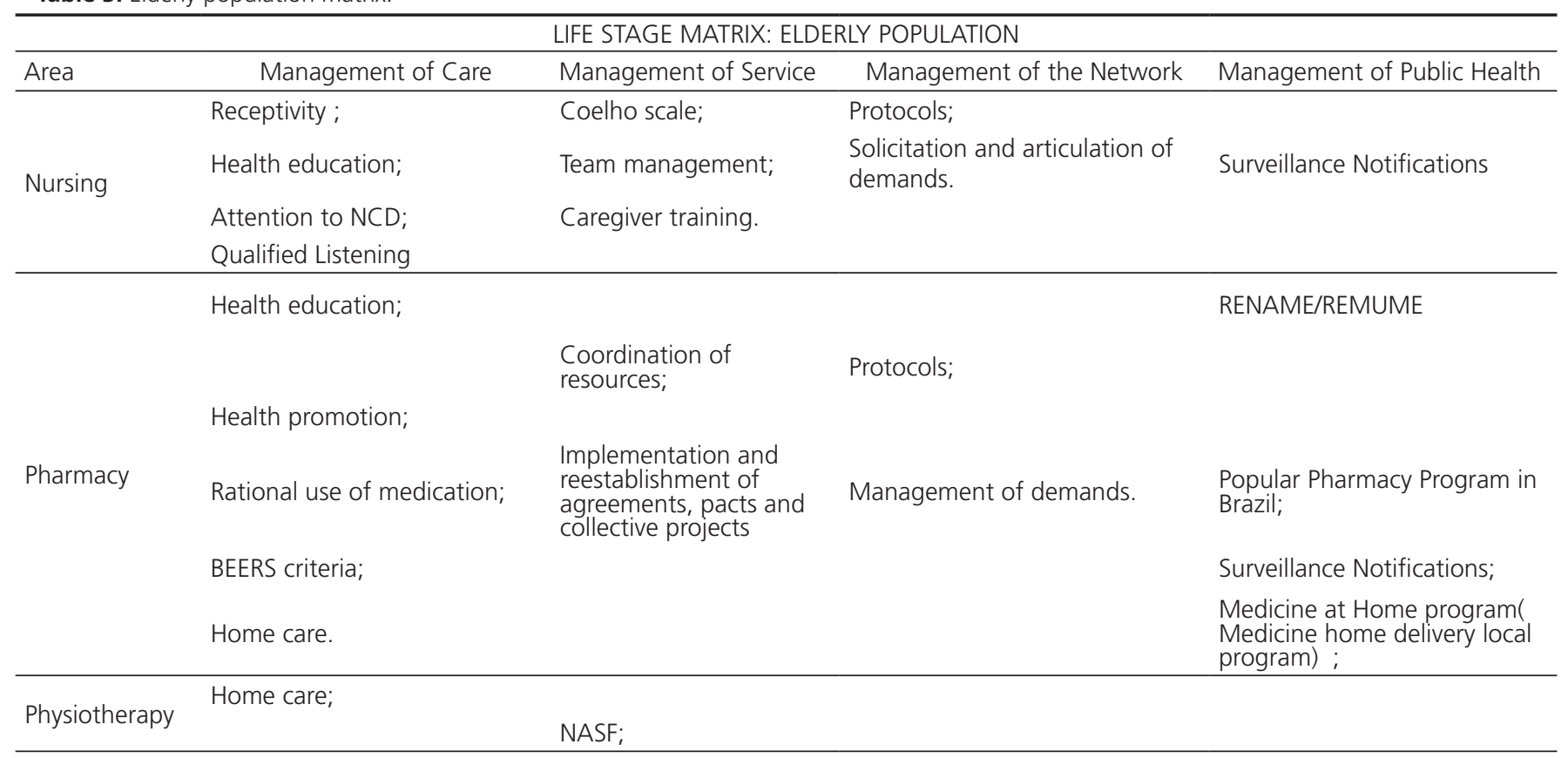




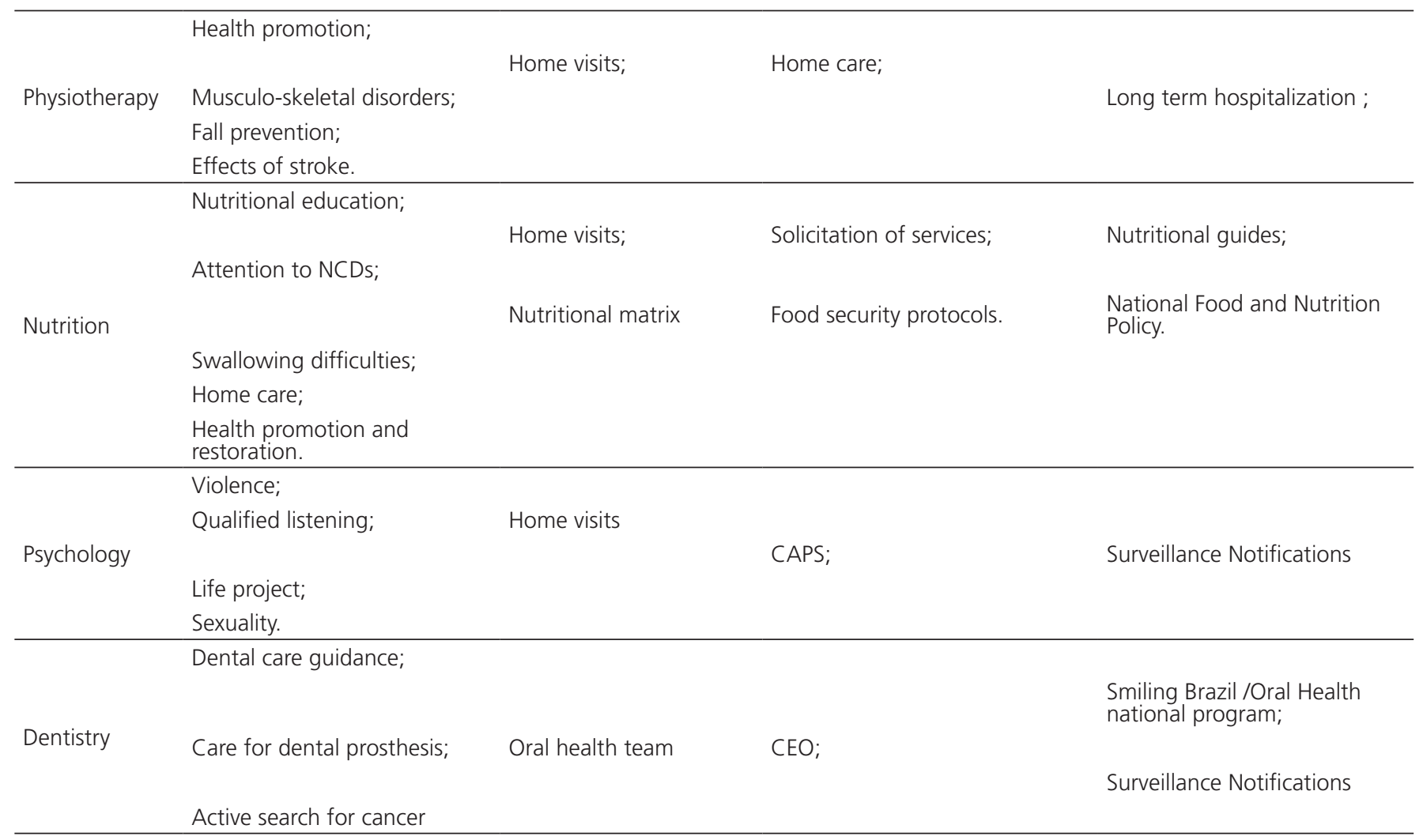

The results presented for the example in Table 3 show that when life stages were discussed, the contributions combined specific knowledge and practices (Prosthesis care, active search for cancer; Swallowing difficulties, BEERS criteria, Musculo-skeletal disorders, fall prevention, and effects of stroke) with contributions common to more than one professional field: qualified listening (nursing, physiotherapy and psychology) and home care (pharmacy, physiotherapy and nutrition). In the service management division, common contributions indicate a rearrangement of work processes or the team: oral health team, home visit team, nutritional matrix, and training of caretakers for elderly. In the management of the network, contributions were made for more professions, related to specific health facilities (CEO, CAPS, specialized rehabilitation center, nutritional matrix support) and the development of guidelines for the network (protocols). In the management of the public health system, intersector actions appear (food security and urban accessibility), as well as contributions about national programs and specific regulatory tasks (notifications and incorporation of medication) presented by almost all professions in the example above.

Table 4 presents a comparison between the most prevalent contributions, by professional area, in each of the workshops during all three stages.

Table 4. Comparative matrix.

\begin{tabular}{llll}
\hline & & COMPARATIVE MATRIX & \\
\hline Area & EACH PROFESSION & VULNERABLE POPULATIONS & STAGES OF LIFE \\
\hline & Attention to NCD; & Health education; & Receptivity; \\
& Vital sign triage; & Treatment for cuts/bruises; & Health Education; \\
Nursing & Home care; & Immunization; & Team management; \\
& Risk classification; & STIs; & Attention to NCDs; \\
& Nursing consultation; & Qualified listening; & Qualified Listening; \\
& Measuring blood pressure and glucose & Encouraging self care & Identification of abuse \\
\hline \multirow{2}{*}{ Pharmacy } & RENAME/REMUME; & Health education; & Health education; \\
& Pharmaceutical assistance and consultation; & Health promotion and recovery; & Health promotion and recovery; \\
\hline
\end{tabular}




\begin{tabular}{|c|c|c|c|}
\hline Pharmacy & $\begin{array}{l}\text { Fick criteria; } \\
\text { Home care; } \\
\text { Rational use of medication }\end{array}$ & $\begin{array}{l}\text { Interaction with drugs; } \\
\text { Receptivity; } \\
\text { Prevention supplies }\end{array}$ & $\begin{array}{l}\text { BEERS criteria; } \\
\text { Access to medication; } \\
\text { Home care. }\end{array}$ \\
\hline \multirow{6}{*}{ Physiotherapy } & Home care; & Self care; & $\begin{array}{l}\text { Neuropsychomotor } \\
\text { development; }\end{array}$ \\
\hline & RN 17-Ergonomics; & Health promotion and recovery; & Musculo-skeletal disorders; \\
\hline & Health promotion and recovery; & Body guidance; & Fall prevention; \\
\hline & ICF; & Qualified listening; & Women's health; \\
\hline & Rehabilitation; & Receptivity; & Active aging; \\
\hline & Body dynamic & Health education. & Cognitive stimulation. \\
\hline \multirow{6}{*}{ Nutrition } & Food pyramid; & Nutritional education; & Attention to NCDs; \\
\hline & Welcoming; & Food security; & Swallowing difficulties; \\
\hline & Evaluation of nutritional state; & Qualified listening; & Home care; \\
\hline & Model plate; & Meal schedule; & Breastfeeding; \\
\hline & Label identification; & Organize access to food; & Nutritional supplements; \\
\hline & True/false quiz about food. & Health promotion and recovery & Adequate hydration. \\
\hline \multirow{6}{*}{ Psychology } & Behavioral analysis; & Create STP; & Violence; \\
\hline & Techniques for dealing with grief/crying; & Qualified listening; & Qualified listening; \\
\hline & $\begin{array}{l}\text { Techniques for dealing with people in violent } \\
\text { situations; }\end{array}$ & Receptivity; & Life project; \\
\hline & Psychotherapy; & Team support; & $\begin{array}{l}\text { Anxiety and depression } \\
\text { prevention; }\end{array}$ \\
\hline & Free of labels workshop & Matrix support; & Sexuality; \\
\hline & & Permanent education & Family planning \\
\hline \multirow{5}{*}{ Dentistry } & Assisted tooth brushing; & Dental care guidance; & Dental care guidance; \\
\hline & Oral hygiene x culture; & Health education; & Care for prosthesis; \\
\hline & Facial harmonizing; & Qualified listening; & Health at school; \\
\hline & Tobacco x cancer; & Lesions and infections; & Active search for cancer; \\
\hline & Supervised tooth brushing workshop & Matrix support & Self care \\
\hline
\end{tabular}

The data on Table 4 shows that once the themes are no longer related to a profession's specific field, but are instead about vulnerable populations or stages of life, the following contributions appear: welcoming receptivity, qualified listening receptivity, health education, health promotion, team management, correct immunization and prevention of Sexually Transmitted Infections (nursing); welcoming, health education, health promotion, interaction with drugs; welcoming receptivity, qualified listening, self care, active aging, body guidance (physiotherapy); nutritional education, food security, breastfeeding (nutrition); welcoming recpetivity, qualified listening, team support, development of Individual Therapeutic Plans (psychology); Qualified listening, health education, prosthesis care, and observation of lesions and infections. It is not possible to determine if the expansion of contributions made by each professional area is directly related to the change in theme, since it could be simply an evolution in the residents' learning process, considering that the workshops were held successively, allowing for an expansion of the offerings through the meetings and discussions.

However, it is possible to observe, especially in the workshops based on the vulnerable populations, whose production of knowledge and practices by profession is limited, how much the contributions made by the residents are shared among primary health care professions. In this sense, the themes led to an interaction between professions and a clearer recognition of the role of a multiprofessional team compared to the the first stage. We also observed that field-specific contributions returned in the third stage, perhaps because the production of knowledge related to life stages, fragmented into fieldspecific training, becomes more frequent and expressive.

The health education strategy for the development of this content is the interaction between the knowledge and practices of specific professions which take part at this multiprofessional residency program. It occured through succesives workshops, mediated by reading references materials and the same professor. One can see an expansion 
of this interaction between different professional areas, as well as of the content in the results of the matrices. This expansion in the contributions is a product of the shared production among the multiprofessional team, not only of specialized knowledge, practices or institutional tasks. One can also notice an expansion in the contributions about the management of services, including contributions about team organization, organization of working processes and interactions with the health services network. The expansion of the association with management of health policies and a greater interaction from each professional field with this dimension and their intersectionality is also described.

\section{DISCUSSION}

The results described in this study interact and contribute to other moments of interprofessional relations among the program residents, between them and the professors/tutors in the practical arena, and with the permanent reality of the services: (a) the discussions with professionals from the health network about the workshops on stages of life, vulnerable populations and others chosen by the residents; (b) the meetings to discuss cases and develop individual therapeutic plans for difficult cases that arise during practice. Both stand out as moments for applying the established content and collectively reflection, offering new questions and presenting new possibilities.

The guiding principle of interprofessional training is that practice develops a field for traditional uniprofessional knowledge to face teamworking, for the discussion of each professional roles, a commitment to solving problems and negotiating therapeutic decision, as pointed out by Batista [10]. Integration means thinking of new interactions during teamwork, organizing an exchange of experiences and knowledge, respecting diversity, cooperating to implement transformative practices and establish partnerships in the development of projects. In this sense, interprofessional education must be dedicated to three skills: skills common to all professions, skills specific to each professional field, and collaborative skills, based on the educational premises of adult learning, interaction-based learning and practice-based learning, as also explained by Batista.

Learning about other professions, its knowledge and practices, within the context of primary health care, therefore, presents a moment to legitimate the history of the different individuals/disciplines involved, and to identify the common or complimentary points necessary for a health team to be able to work in an interdisciplinary way.

However, the initiative analyzed here reveals the importance of confronting established knowledge and practices in each professional field with new objects that can lead to reflections and interactions between professionals, contributing to an expansion of perspectives and contributions from each professional area. The results showed gains in the interaction between professional fields and the field of primary health care, and between this field and the organization of services, of the health services network, and with the totality of health policies. This happened when the themes for reflection were not the knowledge and practices specific to each profession. It was stronger when it was triggered by the contributions each professional field can produce, according to the patient, and the need to interact with the dimensions of management of service, of the health care network, and of health policy.

Here we highlight two elements of the methodological initiative that may have contributed to this expansion: a) the fact that the methodology included second-year residents from the program who, during the first year, had systematized their knowledge according to the knowledge, practices and tasks instituted for each professional field, offering an important level of reflection as they experienced a different methodological strategy in which other themes served as starting points, and were able to share this experience with the group; and b) the presence of the same professor during all 3 stages, exercising the concept of teaching the students to "learn how to learn."

Apparently the interdisciplinary nature the themes for reflection contributed to the expansion of perspectives and a greater interaction with territories that had not been exercised before, such as the organization of services, management of the health network, and public health policies. At the same time, it promoted a permanent tension between areas of knowledge and greater detail of their origins, meanings and concrete practices, fueling a deeper understanding of specific knowledges and practices, as well as a mediation with their limits and insufficiencies. In a way, it exercises future professionals how to overcome any possible rigidity in relation to pre-established knowledge, expanding the challenges to the knowledge specific to their professional field, as well as to any new ones developed or awakened in these interprofessional meetings. 
Here we refer to a reflection by Minayo [11] in which the term interdisciplinarity is an articulation among various disciplines, interacting with an object/ problem/subject for which the contribution from just one of the disciplines is not sufficient. As we have seen in the initiative being analyzed, interdisciplinarity operates with the development of knowledge and practices sparked by this interaction. In this sense, the matrix thought process, by overcoming vertical relations (between commander and commanded, the holder of knowledge and the receiver of knowledge), creates an environment for shared interaction and construction. It creates exchange paths between professional fields around an object which must be worked on collaboratively.

One must emphasize the fact that the residents noted a limited possibility for interaction with the other dimensions beyond the management of care. There is also a separation between health care and the other dimensions of management, but the identification of this separation in itself allows for this content to be covered. In this sense, it is important for multiprofessional residency programs to exercise in Primary Health Care what Ceccim and Feuerwercker [12] have called the "education quadrilateral": the experimentation and experience by residency programs of the contexts for theoretical study, health policy management,primary care and society policy control. We must expand the professional's field of reflection beyond the territory of care, focused on specific consultations or collective practices traditionally implemented at the Basic Health Units.

The contribution offered by this reflection is worth noting, since it is part of each professional's daily contributions. Usually the expansion of professional activity happens with support from previously established field-specific knowledge and practices, exposing their insufficiencies. The challenge comes from how the process of exchanging field-specific knowledge and practices within a multiprofessional educational program leads to a moment of territorial expansion for each professional field in the set of residents, rather than a retraction for specific contents or of the role traditionally occupied by each profession.

We have concluded that, for the methodological changes, new strategies are needed to understand this expansion through interprofessional reflections. While it was not the methodological object of the present study, Deleuze [13], through his reflections on existential territories and essays about health work written by Merhy
[14], used a cartographic model for these reflections, which could be an interesting strategy to consider its limitations and create changes in the methodological models related to interprofessional relations.

\section{REFERENCES}

1. Campos GWS. Reforma da reforma: repensando saúde. São Paulo. Hucitec; 1992.

2. Andrade LO. O dilema da intersetorialidade: um estudo de caso [tese]. Campinas: Universidade Estadual de Campinas; 2004.

3. Merhy E. Em busca do tempo perdido: A micropolítica do trabalho vivo em saúde. In: Emerson E, Onocko R. Agir em saúde: um desafio para público. São Paulo. Hucitec; 1997. p. 71-112.

4. Aires JRCM. Organização das ações de atenção à saúde: modelos e práticas. Saúde Soc. 2009;18(2): 11-23.

5. Ceccim RB. Equipe de saúde: a perspectiva interdisciplinar na produção de atos terapêuticos. In: Pinheiro R, Mattos RA, org. Cuidado: as fronteiras da integralidade. São Paulo: Hucitec; 2004. p. 259-78.

6. Kalichman AO, Ayres JRCM. Integralidade e tecnologias de atenção a saúde: uma narrativa sobre contribuições conceituais a construção do princípio da integralidade no SUS. Cad Saúde Pública. 2016;32(8): 566-582. http://dx.doi.org/10.1590/0102$311 \times 00183415$

7. Brasil. Ministério da Saúde. Secretaria-Executiva. Núcleo Técnico da Política Nacional de Humanização. Humaniza SUS: Política Nacional de Humanização: a humanização como eixo norteador das práticas de atenção e gestão em todas as instâncias do SUS Brasília: Ministério da Saúde; 2004.

8. Brasil. Ministério da Saúde. Portaria n. 2.488, 21 de outubro de 2011. Aprova a Política Nacional de Atenção Básica, estabelecendo a revisão de diretrizes e normas para a organização da Atenção Básica, para a Estratégia Saúde da Família (ESF) e o Programa de Agentes Comunitários de Saúde (PACS). Brasília: Ministério da Saúde; 2011.

9. Brasil. Ministério da Saúde. Secretaria de Gestão do trabalho e educação na saúde. Residência multiprofissional em saúde: experiências, avanços e desafios. Brasília: Ministério da Saúde; 2006.

10. Batista SH, Rossit R, Batista NA. Educação interprofissional, interdisciplinaridade e a formação em saúde: potências e desafios. In: Silva GTR, org. Residência multiprofissional em saúde: vivências e cenários da formação. São Paulo: Martinari; 2013. p. 29-46.

11. Minayo MCS. Disciplinaridade, interdisciplinaridade e complexidade. Emancipação. 2010;10(2): 435-442.

12. Lenoir Y. Didática e interdisciplinaridade: uma complementaridade necessária e incontornável. In: Fazenda ICA, org. Didática e interdisciplinaridade. Campinas: Papirus; 1998. p. 45-75. 
13. Feuerwerker L, Sena R. Contribuição ao movimento de mudança na formação profissional em saúde: uma avaliação das experiências. Interface. 2002; 6(10):37-50. http://dx.doi. org/10.1590/S1414-32832002000100004

14. Alvarez J, Passos E. cartografar e habitar um territorio existencial. In: Passos E, Kastrup V, Escossia L, org. Pistas do metodo cartografico. Porto alegre: Sulina; 2009. p 131-49.

15. Merhy EE. Saúde: a cartografia do trabalho vivo. Coleção Saúde e Debate. Hucitec; 2002. p. 145.

\section{GLOSSARY}

Beer-Fick criteria: Identifies potentially inappropriate medications for elderly (PIM). The use of PIM associated with pharmacological therapy with a variety of pharmaceutical products increases the incidence of adverse effects.

CAPS - Centro de Atenção Psicossocial (Psychosocial Attention Center): Works under an interdisciplinary perspective and tends primarily to people within its territory with mental suffering or mental disorders, including those with needs resulting from the use of alcohol or other drugs, be they in a crisis situation or in the process of psychosocial rehabilitation, and work as a substitute to the asylum model.

CEO - Centro de Especialidades Odontológicas (Center for Dentistry Specialties): Health establishments participating in the National Health Establishments Registry (Cadastro Nacional de Estabelecimentos de Saúde - (NES), classified as Specialized Clinic or Specialized Outpatient Clinic.

CHA - Community Health Agent: A trained professional from the community itself, acting and taking part in the health services offered in their location. They play an important role in welcoming, since they are a member of the health team and of the community, facilitating the creation of bonds with users of the Public Health System (Sistema Único de Saúde - SUS) and allowing for direct contact with the team.

ICF - International Classification of Functioning, Disability and Health: Systematically groups and organizes different aspects of a person with a certain health condition, and what a person with a disease or disorder can or cannot do.

LRPD - Laboratório Regional de Prótese Dentária (Regional Dental Prosthesis Laboratory): Establishment that offers services for total dental prosthesis, partial removable dental prosthesis and/or coronary/intraradicular prosthesis and fixed/adhesive prosthesis.
16. Barr H. Competent to collaborate; towards a competencybased model for interprofessional education. J Interprofessional Care. 1998;12(2):181-8

Received on: $X X / X / X X X X$ Final version resubmitted on: $X X X X X X X X$ Approved on: $X X|X| X X X X$

NASF - Núcleo de Apoio a Saúde da Família (Family Health Support Group): Interdisciplinary team that works in an integrated fashion, supporting the professionals in the Family Health Teams and the Basic Care Teams for specific populations, sharing health knowledge and practices in the territory under the responsibility of these teams.

NCD - Noncommunicable Chronic Diseases: Multifactorial diseases that affect many systems in the human body. Examples include dental cavities, obesity, diabetes, hypertension, stroke, osteoporosis, and cancer of multiple organs, as well as coronary artery diseases.

PAIF - Proteção e Atenção Integral à Família (Integral Protection and Attention to the Family): Has the objective of supporting families, preventing the breaking of bonds, promoting access to rights, and contributing to improvements in the quality of life.

RAPS - Rede de Atendimentos Psicológicos Sociais (Network for Social Psychological Treatment): Establishes the places of care for treating people with mental problems, including the harmful effects of crack, alcohol and other drugs. The Network is part of SUS.

RN-17 - Regulatory Norm 17 - Ergonomics: Establishes the parameters that allow for the adaptation of work conditions to the psycho-physiological characteristics of workers, in order to offer maximum comfort, safety and efficient performance.

REMUME - Relação Municipal de Medicamentos (Municipal List of Medications): Considers additions to the number of essential medications considered basic and indispensable in their appropriate pharmaceutical forms, and creates a reference list that serves as basis for the treatment of diseases. It is a considerable advancement for the improvement of municipal pharmaceutical assistance, especially by supporting the rational use of medication and, as a consequence, the health care of the population.

RENAME - Relação Nacional de Medicamentos Essenciais (National List of Essential Medications): An 
essential tool for guiding standardization, be it for prescription, for supplies of medications, especially within SUS, serving as a mechanism to reduce the costs of products.

STI - Sexually Transmitted Infections: Contagious infections whose most frequent form of transmission is through sexual relations (mainly vaginal, oral or anal).

STP - Singular Therapeutic Project: Instrument for potential care of users of specialized health services, as well as a tool to organize and sustain activities in the Family Health Support Group, based on the concepts of co-responsibility and integrated management of care.

SUS - Sistema Único de Saúde (Universal Health System): A set of health actions and services offered by public institutions and organs at the federal, state and municipal level, by direct and indirect Management, and by foundations maintained by the government.

UBS - Unidade Básica de Saúde (Basic Health Unit): The main entry point and center of communications with the entire Health Care Network. They are installed near where people live, work, and study, playing a central role in safeguarding access to health. 